\title{
160 years of Australian telecommunications
}

\author{
Peter Gerrand \\ Managing Editor
}

\begin{abstract}
Summary: The Australian telecommunications industry has reached its $160^{\text {th }}$ anniversary this year measured from the completion of its first electrical telegraph network on 3 March 1854, linking Melbourne to Williamstown. The back story to the implementation of that first network suggests that Lieutenant Governor Charles La Trobe and the colony's first GeneralSuperintendent of Telegraphy, Samuel McGowan, should be celebrated as the founders of Australian telecommunications: the visionary and his appointee, the entrepreneurial project manager. A brief overview is given of how the Australian telecommunications industry has evolved to the present day, including the evolution of the Telecommunications Society of Australia (now TelSoc), a society of volunteers supporting the industry since 1874, i.e. for 140 years of the industry's 160 years.
\end{abstract}

\section{Introduction}

A plaque on the wall of what later became an extension of the Victorian Supreme Court building in William St, Melbourne provides evidence of the birth of the modern Australian telecommunications ${ }^{1}$ industry here, 160 years ago:

'The First Telegraph Office in the Southern Hemisphere opened for business on this site on $3^{\text {rd }}$ March 1854, for the transmission of telegrams to and from Williamstown'. 


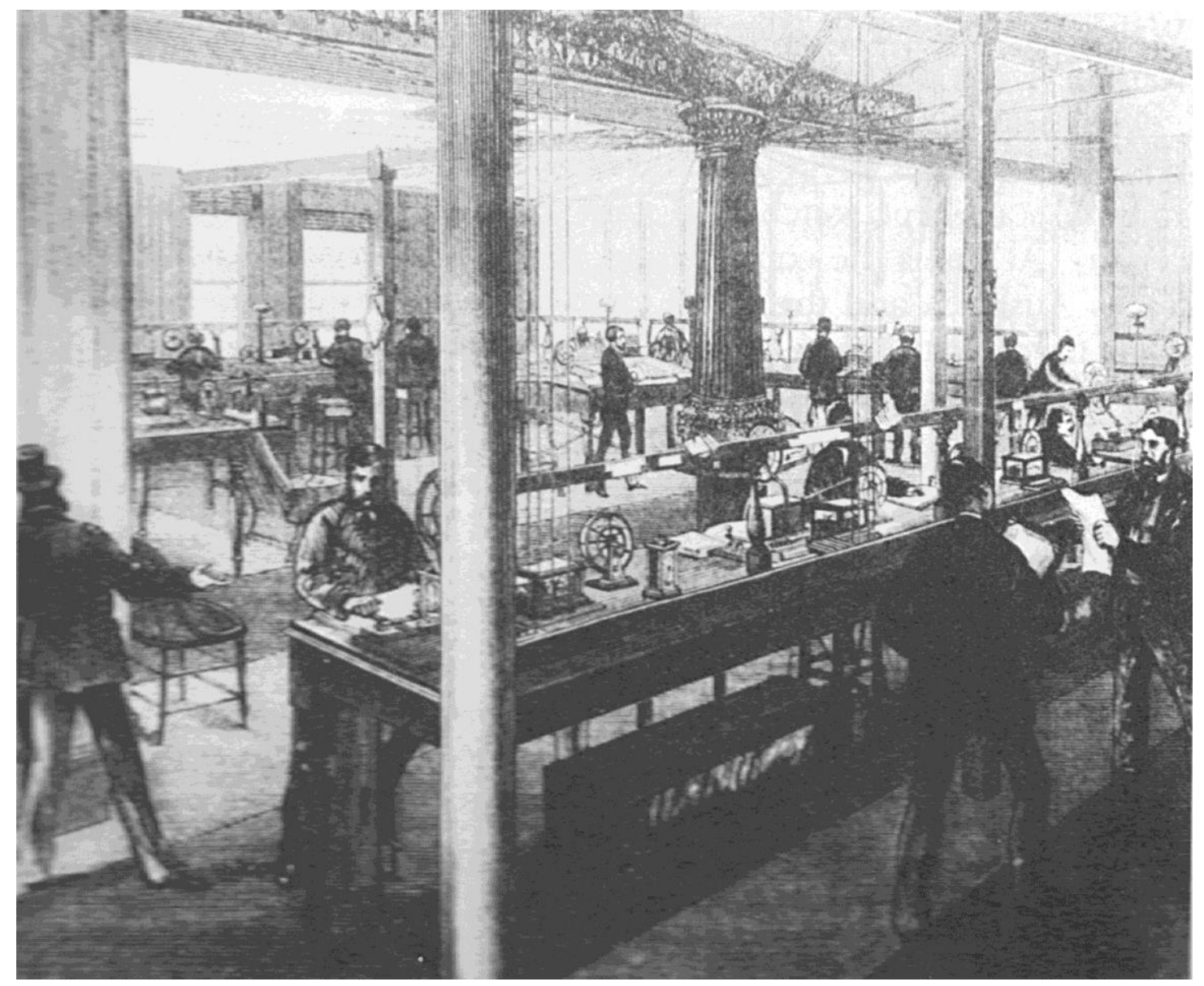

Figure 1 - A sketch of the Melbourne Telegraphy office c. 1870. Source: (Moyal 1984: 31).

\section{The back story}

The background to the first telecommunications network in Australia is quite interesting.

Attracted by the potential of the Australian Gold Rush, a young Canadian entrepreneur, Samuel McGowan, arrived in Melbourne in 1853 with boxes of Morse code sets, batteries and insulators, a set of testimonials and a copy of the Canadian Telegraph Act of 1846. McGowan was an experienced telegraphist who had been an apprentice to Samuel Morse and later became a salesman canvassing subscriptions for private telegraph companies in the USA. (Moyal 1984: 16-18). It would seem he had the intent of creating a commercial telegraphy enterprise like Western Union across the wealthy colonies of Australia, with himself as head.

The local Lieutenant Governor, Charles La Trobe, saw the importance of telegraphy for the growth of the Colony of Victoria, and the Victorian colonial government gave McGowan a contract to prove the new technology by installing and operating a link between the port of Williamstown and the city of Melbourne. Once this was completed - on $3^{\text {rd }}$ March $1854-$ and demonstrated to work, a position of General-Superintendent of a new Electric Telegraph 
Department of the Colony was gazetted, and La Trobe persuaded McGowan to take up this government position rather than pursue his original plans in the private sector (Moyal 1984: 17-18).

La Trobe is best known these days as having fought the developers of his day to create the beautiful inner city parks which lend Melbourne much of its character as a liveable city, especially its Botanical Gardens; and for his leadership and support of major civic projects, such as establishing the University of Melbourne, the Royal Melbourne Hospital and the Mechanics Institute (later to become RMIT University) (ADB 1967). But in his vision for the role of electrical telegraphy as vital communications infrastructure for the growing colonies, and the actions he took to implement that vision in his own area of influence, La Trobe surely deserves to be also known as the Father of Australian telecommunications, jointly with the entrepreneurial McGowan.

La Trobe gave McGowan the mission of connecting Melbourne to the goldfield towns of Bendigo and Ballarat, to the port of Geelong, and to the borders of the adjacent states at Bordertown and Albury. All these projects were implemented within three years, and over the next 20 years Victoria became criss-crossed with telegraph lines. (Moyal 2014: 18)

The rapid rollout of infrastructure, both telegraphy and railways, was only possible through the government revenues achieved by appropriate taxing of the booming mining industry - a political skill which seems to have been lost in recent years - as well as sale of land made more accessible through the rollout. But it also depended on two other factors: the entrepreneurial culture in the new colony, whose gold rush had attracted many skilled immigrants; and the technical expertise needed for network planning, equipment design and manufacture, and to train the telegraphy operators. Much of this expertise was developed in the workshops of the colony's Electrical Telegraph Department.

\section{Creation of the industry's first learned society}

Ann Moyal's magisterial history of Australian telecommunications (1984) shows that entrepreneurship in telegraphy flourished in several of the Australian colonies, particularly in South Australia. The completion of the Overland Telegraph Line by Charles Todd in 1872 caught the public imagination and was a major stimulus for the creation in Melbourne in 1874 of a new technical society, the Telegraphy Electrical Society, whose aim was 'The promotion of the knowledge of electricity, especially as connected with telegraphy'.

Thus was born the first learned society of the telecommunications industry. The evolution of this society to become, from 1959, the Telecommunications Society of Australia and from 2013, TelSoc, is related elsewhere (Wikipedia 2010-2014; TelSoc 2013), and can be seen to have developed in response to major changes in the industry it serves. 


\section{Evolution of the Australian telecommunications industry}

The telecommunications industry's growth has been stimulated through many phases of technology innovation and industry restructuring, most markedly:

- The introduction of telephony by the private sector from 1879 onwards;

- The nationalization of the supply of public telecommunications services following the Federation of Australia (1901) with new powers under the Constitution;

- The legislated passing of the Postmaster-General Department's monopoly role in telecommunications (1902-1975) to the arms-length government business Telecom Australia (1975-1992); and

- the phased introduction of competition in service delivery in 1991 and 1997, and the staged privatisation of Telecom Australia's successor, Telstra (1993-) , in 1997, 1999 and 2006.

The rate of change in telecommunications technology, throughout the industry's 160 years to date, has been breathtaking. There has been, in overlapping succession, the introduction of electrical telegraphy, telephony, the telex, picturegrams, automatic switching of telephony, wireless transmission, multichannel communication, radio and television broadcasting, satellite transmission, packet switching, the Internet, several generations of mobile communication, ISDN, and broadband multimedia services. In many cases, special technical solutions needed to be devised to suit Australia's unique environmental conditions; and the rollout of essential services such as telephony to rural and remote Australia, with their economically challenging low population densities, was only possible through a consistent policy of cross-subsidy from the revenues achieved in the higher population urban areas, throughout the $20^{\text {th }}$ century.

The 1980 s saw the integration of many of the underlying technologies of the telecommunications and computer industries (to produce 'ICT': the information and communication technologies). From the 1990s, telecommunications became integrated with the Internet; and since the 2000 s with digital broadcasting as well, such as IPTV.

Last year our industry broke several records for growth (ACMA 2014) and looks set for further expansion in supporting 'the Internet of Things'.

\section{Conclusion}

There is a huge amount to be proud of in the history of Australian telecommunications, especially in its key role of support infrastructure for the growth and well being of Australian society and of the Australian economy, across the vast distances of this continent. 
In 2014 it is appropriate to celebrate the achievement of 160 years of continuous innovation and growth since the implementation of Australia's first electrical telegraphy line, in 1854 . And perhaps it is time to give Sir Charles La Trobe, first Governor of the Colony of Victoria, and the Canadian entrepreneur Charles McGowan, some overdue credit for their visionary roles in initiating and implementing Australia's first telecommunications network.

\section{References}

ACMA. 2014. Communications report 2012-13, updated 2 January 2014, at http://www.acma.gov.au/theACMA/Library/Corporate-library/Corporatepublications/communications-report-2012-13

ADB (Australian Dictionary of Biography). 1967. 'La Trobe, Charles Joseph (1801-1875), at http://adb.anu.edu.au/biography/la-trobe-charles-joseph-2334

Gerrand, Peter. 2010. 'Celebrating 75 years of the Telecommunications Journal of Australia', Telecommunications Journal of Australia, Vol. 60. No. 3, August 2010, doi:10.2104/tja10046

ITU. 2004. 'History'. At http://www.itu.int/en/about/Pages/history.aspx

Moyal, Ann. 1984. Clear across Australia: a history of telecommunications. Nelson, Melbourne.

TelSoc. 2013. 'History of TelSoc', at https://telsoc.org/history/history telsoc

Wikipédia. 2014. 'Édouard Estaunié', at http://fr.wikipedia.org/wiki/Édouard Estaunié

Wikipedia. 2010-14. 'Telecommunications Society of Australia', at http://en.wikipedia.org/wiki/Telecommunications Society of Australia

\section{Endnotes}

${ }^{1}$ The word 'telecommunication' was not actually coined until 1904 (as télécommunication), by the visionary French engineer and novelist Édouard Estaunié, during his period as Director of the École Professionnelle Supérieure des Postes et Télégraphes in Paris, 1901-05 (Wikipédia 2014). The word took until 1932 to formally penetrate the English language, without its French accents, when the venerable Union Télégraphique Internationale/International Telegraphy Union/, founded in Paris in 1865, changed its name to the Union Internationale des Télécommunications/International Telecommunication Union/ (ITU 2014). Three years later, in June 1935, the Postal Electrical Societies of the states of Australia combined to produce their first national journal, the Telecommunication Journal of Australia (Gerrand 2010) - the immediate predecessor of the Journal you are now reading. 


\section{Cite this article as:}

Peter Gerrand. 2014. 160 years of Australian telecommunications!. Australian Journal of Telecommunications and the Digital Economy, Vol 2, No 2, Article 43.http://doi.org/10.7790/ajtde.v2n2.43. Published by

Telecommunications Association Inc. ABN 34732327 053. http://telsoc.org 